\title{
Frequency and factors associated with Theileria equi, Babesia caballi and Trypanosoma evansi in equids from Bahia (Northeast Brazil)
}

Frequência e fatores associados a Theileria equi, Babesia caballi e Trypanosoma evansi em equídeos da Bahia (Nordeste do Brasil)

Sonia Carmen Lopo Costa $^{1}$; Jéssica de Souza Freitas ${ }^{1}$; Aísla Nascimento da Silva ${ }^{1}$; Luciana Carvalho Lacerda ${ }^{1}$; Rebeca Dálety Santos Cruz¹; Fábio Santos Carvalho'; Maria Julia Salim Pereira²; Alexandre Dias Munhoz ${ }^{1 *}$ (1)

\begin{abstract}
${ }^{1}$ Departamento de Ciências Agrárias e Ambientais, Universidade Estadual de Santa Cruz - UESC, Campus Soane Nazaré de Andrade, Ilhéus, BA, Brasil

${ }^{2}$ Departamento de Parasitologia Animal, Universidade Federal Rural do Rio de Janeiro - UFRRJ, Seropédica, RJ, Brasil
\end{abstract}

Received July 19, 2018

Accepted October 22, 2018

\begin{abstract}
The aim of this study was to determine the frequency and factors associated to Babesia caballi, Theileria equi and Trypanosoma evansi in naturally infected equids from the northeast Brazil. Blood samples from 569 equids $(528$ horses, 8 mules, and 33 donkeys) were collected and tested for the presence of DNA of each of these protozoan parasites by PCR. Generalized linear models were used to evaluate risk factors associated with the infection. The frequency of T. equi infection was $83.5 \%(475 / 569)-84.3 \%$ in horses, and $73.2 \%$ in donkeys and mules. The results of the final model indicated that age (senior group) and animal species (mule and donkey group) were protective factors against this pathogen. The frequency of $B$. caballi infection was $24.3 \%(138 / 569)-23.5 \%$ in horses and $34.1 \%$ in donkeys and mules. Age (adult and senior group) was considered a protective factor against B. caballi infection whereas animal species (donkey and mule group) were considered a risk factor for the infection. Trypanosoma evansi infection was not detected in any of animals. Our results suggest that equids from the area studied may be infected earlier in life with the etiological agents of equine piroplasmosis and become asymptomatic carriers.
\end{abstract}

Keywords: Piroplasmosis, trypanosomiasis, epidemiology, horses, mules, donkeys.

\section{Resumo}

Este estudo teve como objetivos conhecer a frequência e os fatores associados à infecção por Babesia caballi, Theileria equi e Trypanosoma evansi em equinos naturalmente infectados do nordeste do Brasil. Amostras de sangue de 569 equídeos (528 equinos, 8 muares e 33 asininos) foram coletadas e testadas para a presença do DNA destes parasitos através da PCR. Modelos lineares generalizados foram utilizados na avaliação dos fatores associados às infecçôes. A frequência de infecção por T. equi foi de 83,5\% (475/569) -84,3\% (445/528) em eqüinos e 73,2\% (30/41) em asininos e muares. Os resultados do modelo final indicam idade (sênior) e espécie (muar e asinina) como possíveis fatores de proteção para este patógeno. A frequência de infecção por $B$. caballi foi de 24,3\% (138/569) - 23,5\% (124/528) em eqüinos e 34,1\% (14/41) em asininos e muares. As faixas etárias (adulto e sênior) foram identificadas como possíveis fatores de proteção, e a espécie (asinina e muar) como risco para ocorrência de infecção por B. caballi. Infecçôes por Trypanosoma evansi não foram detectadas. Estes resultados indicam que os equídeos na região estudada se infectam precocemente com agentes da piroplasmose equina tornando-se portadores assintomáticos.

Palavras-chave: Piroplasmose, tripanosomose, epidemiologia, equinos, muares, asininos.

\section{Introduction}

Equine piroplasmosis (EP) is a major parasitic disease transmitted by ticks to equids (equines, mules, donkeys, and zebras) (DEWAAL, 1992). Most of the cases of EP in equids are

*Corresponding author: Alexandre Dias Munhoz. Universidade Estadual de Santa Cruz - UESC, Campus Soane Nazaré de Andrade, Rod. Jorge Amado, Km 16, Salobrinho, CEP 45662-900, Ilhéus, BA, Brasil. e-mail: munhoz@uesc.br caused by the hemoprotozoa Theileria equi and Babesia caballi (ROTHSCHILD, 2013). Theileria equi is generally more pathogenic and more often detected than B. caballi in areas where both parasites are present (BRÜNING, 1996; RIBEIRO et al.,2013). American trypanosomiasis is caused by Trypanosoma evansi, and is mainly mechanically transmitted by insects of the families Tabanidae and 
Stomoxidae and by hematophagous bats (Desmodus rotundus) as well (HOARE, 1972; LOSOS, 1986).

These hemoparasites are responsible for significant losses to the equine industry, especially in terms of treatment costs of acute infections, abortions, decreased performance, and deaths (ROTHSCHILD, 2013). EP is a disease of international relevance since it imposes restrictions on the transit of infected animals limiting importations, trade, and participation in competitive sports (MUNOZ et al., 2013; RIBEIRO et al., 2013; SANTOS et al., 2009; WEILAND, 1986). In T. evansi infection, the mortality rate may reach $100 \%$ in untreated equids (OIE, 2017).

In the acute form of the disease, animals develop diverse, nonspecific clinical signs including fever, lethargy, anorexia, pale mucous membranes, jaundice, hemolytic anemia (MUÑOZ et al., 2013), thrombocytopenia (BUTLER et al., 2008; DE WAAL, 1992), hepato- and splenomegaly, hemoglobinuria, and bilirubinuria (SANTOS et al., 2009). Major clinical signs of trypanosomiasis due to T. evansi are fever, anemia, progressive weight loss, and lethargy (RODRIGUES et al., 2016) which progress to weakness, cachexia, incoordination, and paralysis with atrophy of the hindlimbs (RODRIGUES et al., 2005; SILVA \& SANCHEZ, 2003).

It is estimated that only $10 \%$ of the global equine population inhabit areas considered free of piroplasmosis. Most tropical and subtropical regions around the world are considered endemic for both equine piroplasmosis and equine trypanosomiasis (SGORBINI et al., 2015).

Epidemiological studies have demonstrated an association between EP and tick infestation (KERBER et al., 2009), age range (QABLAN et al., 2013; SANTOS et al., 2011; VIEIRA et al., 2013), extensive farming (MORETTI et al., 2010; RIBEIRO et al., 2013), geographic area, season of the year, and gender (MORETTI et al., 2010; RÜEGG et al., 2007). These are important factors to consider in the prevention and control of the disease (KERBER et al., 2009). Comparison between results of studies conducted in various regions of the world should be done with great caution. Differences in terms of the diagnostic test used in each study, the climate of the study area, the type of management system adopted by producers, and the methods and criteria of selection of animals in a study can directly influence research results.

In Brazil, T. equi prevalence ranges from $21.6 \%$ to $100 \%$ (BALDANI et al., 2010; KERBER et al., 2009) whereas B. caballi infection varies from $54.1 \%$ to $93.2 \%$ (KERBER et al., 2009; MACHADO et al., 2012). The Central-West region of Brazil is endemic for T. evansi (FRANKE et al., 1994; SILVA et al., 1995). Outbreaks of the disease also occur in the North, Southeast, and South regions of the country (NUNES et al., 2012; RODRIGUES et al., 2005). We conducted a thorough literature review and were unable to find any published references on the molecular diagnosis of these hemoprotozoan diseases in northeast Brazil. The Northeastern region of the country has over 46 million inhabitants, and an estimated equid population of 1,259,850 heads. The State of Bahia, Northeast Brazil, has the third largest equine herd of the country (IBGE, 2015).

The aim of this study was to determine the frequency of Babesia caballi, Theileria equi, and Trypanosoma evansi in naturally infected equids from the microregion of Ilhéus-Itabuna, northeast Brazil, and the laboratory abnormalities and risk factors associated with the occurrence these hemoparasitic infections.

\section{Materials and Methods}

\section{Study area and sample population}

Data was collected between August 2013 and December 2014 in the microregion of Ilhéus-Itabuna, state of Bahia, northeast Brazil. This geographic region is part of the mesoregion of Southern Bahia, and has an estimated equid population of 90,974 animals. The study area is located in the Atlantic forest. The annual average rainfall is $1445 \mathrm{~mm}$, with a relative humidity of $80 \%$, and a temperature of $24^{\circ} \mathrm{C}$ (INMET, 2010). Five counties from this mainly rural microregion have been selected for this study, and were ranked according to the size of their equid population as follows: Itaju

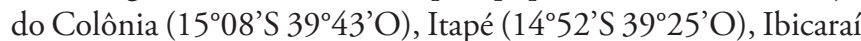

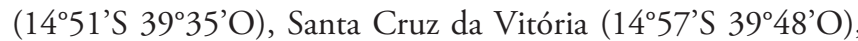
and Floresta Azul (1450'S 39 $\left.39^{\circ} \mathrm{O}\right)$. The county of Itabuna $\left(15^{\circ} 8^{\prime} \mathrm{S} 39^{\circ} 43^{\prime} \mathrm{W}\right)$, which is a mostly urban area, was also included in this survey (Figure 1).

Animals, farms, and counties were selected based on their convenience. The number of animals per county was proportional to their equid population. Blood samples were collected from 569 equidae (528 horses, 8 mules, and 33 donkeys); 516 out 569 equids were from 20 rural properties; 53 horses out of 569 equids were from urban areas and were used by mounted police, to draw coaches, or for horseback ride.

Inorder to evaluate potential risk factors, information regarding signalment (species, age, gender), farm characteristics and management (animal kept in a stable, presence of ticks, contact with other animal species) were obtained through semi-structured interviews with handlers (staff) or owners. Interviews were always conducted by the same researcher.

The study was carried out according to the standards established by the Brazilian College of Ethics and Animal Welfare. The research proposal was approved by the Committee for Ethics in Research with Animals (protocol 002/2013) at Santa Cruz State University, Ilhéus, BA, Brazil.

\section{Sample collection and processing}

Blood (10mL) was collected from each animal by jugular venipuncture using disposable needles $(25 \times 8 \mathrm{~mm})$ connected to vacuum tubes with anticoagulant (EDTA) for complete blood count and DNA extraction. Complete blood count (CBC) was performed on a ABX Vet hematology analyzer $\left(\right.$ Horiba $^{\mathrm{TM}}$ ). Total plasma protein was measured using a traditional handheld refractometer. Blood smears fixed in methanol and stained with Giemsa $\left(\right.$ BIOTEC $\left.^{\circledR}\right)$ were used for differential white blood cell count and direct parasitological examination. These blood films were examined under the light microscope (magnification 1000x).

After completing the CBC, tubes were centrifuged for 10 minutes at $699 \mathrm{~g}$. Total plasma protein concentration was evaluated with supernatant plasma. The supernatant plasma was discarded, and then both the leukocyte layer and the packed red blood cells were removed, poured into plastic tubes free of DNase and RNase, and frozen at $-20^{\circ} \mathrm{C}$ for subsequent DNA extraction. 

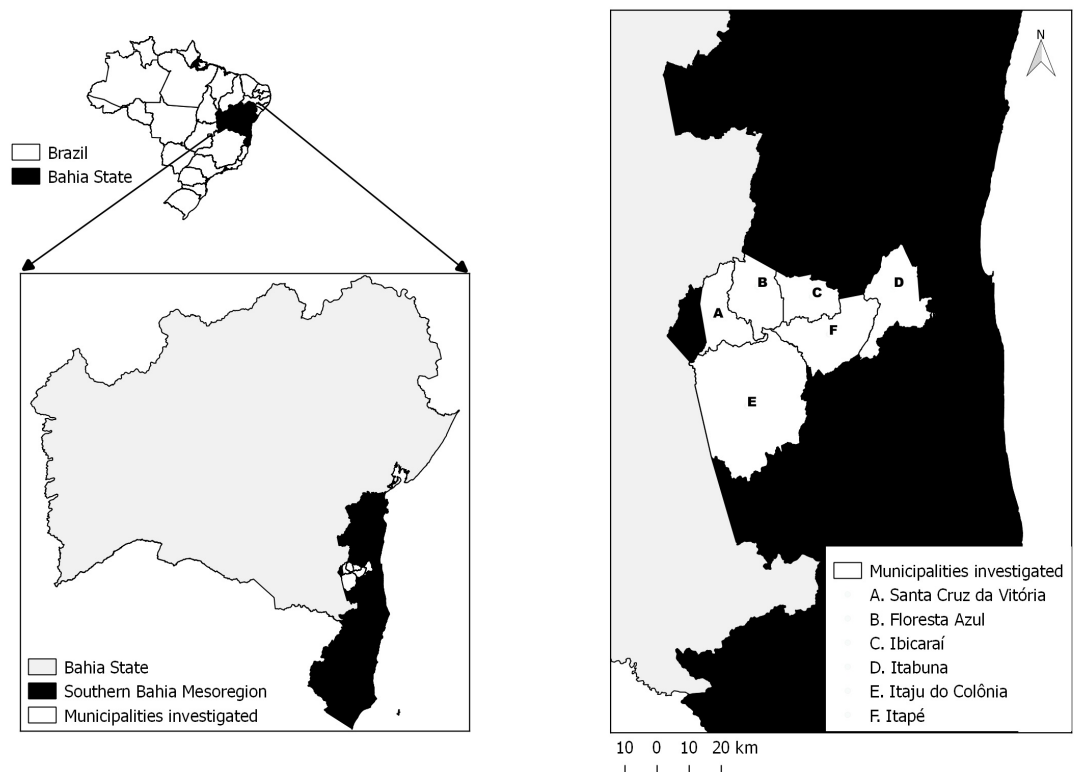

Figure 1. Location of the study area which includes the counties of Itaju do Colônia, Santa Cruz da Vitória, Itapé, Ibicaraí, Floresta Azul, and Itabuna.

Ticks were collected from horses during visits to farms. Taxonomic identification of ticks was performed using a stereoscopic microscope and was based on the morphological keys published by Aragão \& Fonseca (1961), Barros-Battesti et al. (2006), and Martins et al. (2010).

\section{Extraction of DNA from blood samples and molecular diagnosis of hemoprotozoan infection by PCR}

DNA was extracted from blood samples using a commercial QIAamp $^{\circledR}$ DNA Blood Mini Kit (QIAGEN ${ }^{\mathrm{TM}}$ ) according to the manufacturer's recommendations. DNA samples were labeled with accession numbers and stored in a freezer at $-20^{\circ} \mathrm{C}$ for subsequent polymerase chain reaction (PCR). Positive controls were kindly provided by the Laboratory of Immunoparasitology of the São Paulo State University (UNESP), Jaboticabal, SP, Brazil, and obtained from experimentally infected horses as well (BALDANI et al., 2010). Ultrapure water was used as the negative control.

\section{PCR for the detection of Theileria equi}

A nested-PCR for T. equi was performed using the primers and amplification protocols described by Nicolaiewsky et al. (2001). Primers were designed to amplify the ema-1 gene (Table 1). The first PCR reaction consisted of a final volume of $25 \mu \mathrm{L}$ containing $1 \mu \mathrm{L}$ of genomic DNA, 10x reaction buffer, $1.5 \mathrm{mM} \mathrm{MgCl}_{2}, 0.2 \mathrm{mM}$ of each dNTP, $0.5 \mu \mathrm{M}$ of each primer, $0.75 \mathrm{U}$ of Taq polymerase, and ultrapure water to complete the final volume. Tubes were briefly centrifuged and then placed in a MJ96G $\left(\right.$ Biocycler $^{\circledR}$ ) thermal cycler for denaturation at $94^{\circ} \mathrm{C}$ for 4 minutes followed by 40 cycles of $94^{\circ} \mathrm{C}$ for 40 seconds for denaturation, $60^{\circ} \mathrm{C}$ for 1 minute for annealing, extension at $72^{\circ} \mathrm{C}$ for 1 minute, and a final extension at $72^{\circ} \mathrm{C}$ for 4 minutes. $1 \mu \mathrm{L}$ of the product of the first reaction and the same components and concentration of the mix were used for the second PCR reaction. The amplification protocol consisted of initial denaturation at $94^{\circ} \mathrm{C}$ for 4 minutes followed by 35 cycles of $94^{\circ} \mathrm{C}$ for 1 minute for denaturation, $60^{\circ} \mathrm{C}$ for 45 seconds for annealing, extension at $72^{\circ} \mathrm{C}$ for 45 seconds, and a final extension at $72^{\circ} \mathrm{C}$ for 5 minutes.

\section{PCR for the detection of Babesia caballi}

A nested-PCR was performed for the detection of $B$. caballi. Primers developed by Ikadai et al. (1999) were used in the first PCR reaction, and primers developed by Battsetseg et al. (2002) were used for the second PCR reaction. Primers were designed to amplify the rap-1 gene (Table 1). For the first PCR reaction, a final volume of $25 \mu \mathrm{L}$ was used which consisted of $5 \mu \mathrm{L}$ of genomic DNA, $10 \mathrm{x}$ reaction buffer, $1.5 \mathrm{mM} \mathrm{MgCl}_{2}, 0.25 \mathrm{mM}$ of each dNTP, $0.5 \mathrm{mM}$ of each primer, $1.25 \mathrm{U}$ of Taq polymerase, and ultrapure water until the final volume was achieved. The amplification protocol used consisted of initial denaturation at $94^{\circ} \mathrm{C}$ for 4 minutes followed by 40 cycles at $94^{\circ} \mathrm{C}$ for 1 minute of denaturation, annealing at $56^{\circ} \mathrm{C}$ for 2 minutes, extension at $72^{\circ} \mathrm{C}$ for 2 minutes, and a final extension at $72^{\circ} \mathrm{C}$ for 5 minutes. Amplification was carried out according to the protocol published by Ikadai et al. (1999). $1 \mu \mathrm{L}$ of the product of the first reaction and the same components and concentration of the mix from the first reaction were used for the second reaction, and the thermocycling conditions were the same used in the first PCR reaction. We used the amplification protocol published by Battsetseg et al. (2002). 
Table 1. Primers used to perform PCR for the detection of equids naturally infected with hemoparasites, and to verify the DNA integrity and the presence of inhibitors in the blood samples tested.

\begin{tabular}{|c|c|c|c|c|}
\hline Agent & Code & $\begin{array}{c}\text { Sequence of oligonucleotides } \\
\left(5^{\prime}-3^{\prime}\right)\end{array}$ & $\begin{array}{l}\text { Reaction } \\
\text { (Fragment) }\end{array}$ & Reference \\
\hline \multirow[t]{4}{*}{ Theileria equi } & EMAE-F & CCGCCCTTCACCTCGTTCTCAA & $1^{\mathrm{a}}$ & Nicolaiewsky et al. (2001) \\
\hline & EMAE-R & TCTCGGCGGCATCCTTGACCTC & $\left(396 b p^{*}\right)$ & \\
\hline & EMAI-F & CCGTCTCCGTTGACTTGGCCG & $2^{\mathrm{a}}$ & \\
\hline & EMAI-R & GGACGCGCTTGCCTGGAGCCT & $\left(102 b p^{*}\right)$ & \\
\hline \multirow[t]{4}{*}{ Babesia caballi } & $\mathrm{BC} 48 \mathrm{~F} 1$ & ACGAATTCCCACAACAGCCGTGT & $1^{\mathrm{a}}$ & Ikadai et al. (1999) \\
\hline & BC48R3 & ACGAATTCGTAAAGCGTGGCCAT & $\left(530 \mathrm{bp}^{*}\right)$ & \\
\hline & BC48F11 & GGGCGACGTGACTAAGACCTTAT & $2^{\mathrm{a}}$ & Battsetseg et al. (2002) \\
\hline & BC48R31 & GTTCTCAATGTCAGTAGCATCCG & $\left(430 b p^{*}\right)$ & \\
\hline \multirow[t]{2}{*}{ Trypanosoma evansi } & TBR1 & GAATATTAAACAATGCGCAG & $1^{\mathrm{a}}$ & Masiga et al. (1992) \\
\hline & TBR2 & CCATTTATTAGCTTTGTTGC & $\left(164 b p^{*}\right)$ & \\
\hline \multirow[t]{2}{*}{ GAPDH } & gapF & CСТTCATTGACСТCAACTACAT & $1^{\mathrm{a}}$ & Birkenheuer et al. (2003) \\
\hline & gapR & CCAAAGTTGTCATGGATGACC & $\left(400 \mathrm{bp} \mathrm{p}^{*}\right)$ & \\
\hline
\end{tabular}

*Base pairs.

\section{PCR for the detection of Trypanosoma evansi}

PCR for the detection of T. evansi was performed using primers TBR1 and TBR2 that were developed by Masiga et al. (1992) (Table 1). PCR was carried out using a final volume of $25 \mu \mathrm{L}$ containing $10 \mu \mathrm{L}$ of genomic DNA, $10 x$ reaction buffer, $1.5 \mathrm{mM} \mathrm{MgCl}$, $0.2 \mathrm{mM}$ of each dNTP, $1 \mu \mathrm{M}$ of each primer, $1 \mathrm{U}$ of Taq polymerase, $2.5 \mu \mathrm{L}$ of BSA (bovine serum albumin, Sigma, Brazil), $0.9 \mu \mathrm{L}$ of DMSO D2650 (Sigma, Brazil), and ultrapure water until the final volume was achieved. The amplification protocol used was the one published by Ashour et al. (2013) with modifications, and included an initial denaturation step at $94^{\circ} \mathrm{C}$ for 10 minutes followed by 40 cycles at $94^{\circ} \mathrm{C}$ for 30 seconds for denaturation, annealing at $50^{\circ} \mathrm{C}$ for 45 seconds, extension at $72^{\circ} \mathrm{C}$ for 10 seconds, and a final extension performed at $72^{\circ} \mathrm{C}$ for 10 minutes.

\section{PCR for the detection of GAPDH (glyceraldehyde-} 3-phosphate dehydrogenase)

In order to verify DNA integrity and the presence of potential inhibitors, negative samples were subjected to PCR for the detection of the GAPDH gene using primers developed by Birkenheuer et al. (2003) (Table 1). In the PCR reactions, we used the final volume of $25 \mu \mathrm{L}$, composed of $5 \mu \mathrm{L}$ of genomic DNA, 10x reaction buffer, $2.0 \mathrm{mM} \mathrm{MgCl}, 0.2 \mathrm{mM}$ of each dNTP, $0.4 \mu \mathrm{M}$ of each primer, $1.25 \mathrm{U}$ of Taq polymerase, and ultrapure water until the final volume was achieved. The amplification protocol used was the one published by Lacerda et al. (2017), and consisted of a initial denaturation step at $95^{\circ} \mathrm{C}$ for 5 minutes followed by 40 cycles of $94^{\circ} \mathrm{C}$ for 30 seconds for denaturation, annealing at $52^{\circ} \mathrm{C}$ for 1 minute, extension at $72^{\circ} \mathrm{C}$ for 1 minute, and a final extension step at $72^{\circ} \mathrm{C}$ for 5 minutes.

PCR products were detected by $2 \%$ agarose gel electrophoresis on a TAE running buffer ( $40 \mathrm{mM}$ Tris-acetate, $2 \mathrm{mM} \mathrm{EDTA} \mathrm{pH} \mathrm{8.0).}$ The gel was run at $80 \mathrm{~V}, 180 \mathrm{~mA}$ for 30 minutes, and then stained with ethidium bromide $(0.5 \mu \mathrm{g} / \mathrm{mL})$. A standard primer pair $(1 \mathrm{~Kb}$ Plus DNA Ladder - Invitrogen $\left.{ }^{\circledR}\right)$ was used to estimate the size of the amplified products. Amplified products were visualized under a ultraviolet (UV) transilluminator (LPIX, LoccusBiotecnologia ${ }^{\circledR}$ ) and photographed on a coupled image analyzer.

\section{Statistical analysis}

In order to evaluate the influence of hemoparasite infection on all the parameters in the CBC and total plasma protein of equids, animals were divided into two groups: one group was composed of animals that tested positive for hemoparasites and another group was formed by animals that tested negative for hemoparasites. A comparison was carried out within each age group. The Student's $t$-test was used to compare the averages with a significance level of $5 \%$. Frequency distribution between animals from rural areas and animals from urban areas was compared using the chi-square test.

The variables were categorized for purposes of statistical modeling as follows: species (equine/donkey + mule) (LINHARES et al., 1997); age which was converted into age ranges, i.e. young ( $\leq 3$ years), adult ( $>3$ and $<12$ years), and senior ( $\geq 12$ years)] (VIEIRA et al., 2013), gender (male/female) (RÜEGG et al., 2007), equid kept in a stable (yes/no) (MORETTI et al., 2010), equid had contact with sheep (yes/no), equid had contact with goats (yes/no), equid had contact with poultry (yes/no), equid had contact with cattle (yes/no) (SANTOS et al., 2011), presence of rats in the farm (yes/no), and presence of toxic plants in the pasture (yes/no). The presence of T. equi, B. caballi, and T. evansi infection (yes/no) were considered as outcome variables.

Blood samples from animals from urban areas were collected only in the county of Itabuna; a total of 53 horses were sampled including those used by the mounted police, to draw coaches, or for horseback ride. These animals were excluded from the modeling due to the different management practices applied to these horses.

Generalized linear models with binomial distribution were used to perform bivariate and multivariate analyses. Due to the possibility of clusters, intraclass correlation coefficients (ICCs) for counties and farms were calculated (DOHOO et al., 2003) from the null model (STARKWEATHER, 2010). In the case of cluster formation, the variable was considered random, and generalized linear mixed models were used for the analyses.

The modeling strategy used in the multivariate analyses was backward elimination, in which all variables were initially included in the model. In this initial model, in each step the variables were selected based on the Wald test until the most parsimonious model that best explained the outcome was obtained. The significance level for a variable remaining in the final model was set at 5\%. 
The Akaike Information Criterion (AIC) was used to evaluate the fit of the models.

Odds ratios (OR) and their respective $95 \%$ confidence intervals (CI) were calculated based on the regression coefficients estimated by the models. Statistical calculations were performed with a $\mathrm{R}$ program version 3.2.5 for Windows (R DEVELOPMENT CORE TEAM, 2016) using a lmer4 package (BATES et al., 2015), version 1.1-12.

\section{Results}

In the present study, $83.5 \%$ of the equids (475/569) were positive for T. equi by PCR; $84.3 \%$ (435/516) of these animals were from rural areas whereas $75.5 \%$ (40/53) were living in urban areas $(p>0.05)$. Equids positive for hemoparasites were detected in all counties and farms with a percentage of positivity ranging from 75.5 to $88.1 \%$ in each county, and from 54.5 to $100 \%$ in each farm; $84.3 \%$ (445/528) of horses, $72.7 \%$ (24/33) of the donkeys, and $75 \%(6 / 8)$ of mules were positive for hemoparasites. The ICCs for the municipalities $(0.5 \%)$ and farms $(1.1 \%)$ did not indicate the formation of clusters. Generalized linear models therefore were used. Tables 2 and 3 show the changes in all variables in the bivariate and the multivariate analyses (full model), respectively. The final model (Table 4) shows the senior age group and the other species (donkey + mule) as possible protective factors.

For B. caballi, by PCR, 24.3\% (138/569) of the animals tested positive, $25 \%(129 / 516)$ in the rural population and $17 \%(9 / 53)$ in the urban population ( $\mathrm{p}>0.05)$. Similarly, for T. equi, positive equids were identified in all studied counties and farms, with a percentage of positive animals varying from 18.8 to $32.7 \%$ in the counties and from 9 to $66.7 \%$ in the farms. The analyses found that $23.5 \%$ (124/528) of horses were positive, 30.3\% (10/33) of donkeys were positive, and 50\% (4/8) of the mules were positive. The ICCs (intraclass correlation coefficients) for the counties $(0.9 \%)$ and farms $(4.5 \%)$ indicated clusters only at the farm level. Therefore, generalized linear mixed models taking a farm as the random effect were used for the analysis of possible risk factors for the occurrence of $B$. caballi infection. Changes in all variables from both the bivariate and the multivariate analyses (full model) are shown in Tables 5 and 6. In the final model (Table 7), the

Table 2. Generalized linear models for factors associated with Theileria equi infections in naturally infected equids from the Ilhéus-Itabuna microregion, State of Bahia, Northeast Brazil. Bivariate analysis.

\begin{tabular}{|c|c|c|c|c|c|c|}
\hline \multirow{2}{*}{ Variable } & \multicolumn{4}{|c|}{ Equidae } & \multirow{2}{*}{$\begin{array}{c}\text { Odds ratio } \\
(95 \% \text { CI })\end{array}$} & \multirow{2}{*}{$P$} \\
\hline & \multicolumn{2}{|c|}{ Positive (\%) } & \multicolumn{2}{|c|}{ Negative (\%) } & & \\
\hline \multicolumn{7}{|l|}{ Sex } \\
\hline Male & 121 & 85.8 & 20 & 14.2 & $1.18(0.68-2.03)$ & 0.56 \\
\hline Female (Ref) & 314 & 83.7 & 61 & 16.3 & & \\
\hline \multicolumn{7}{|l|}{ Species } \\
\hline Horses (Ref) & 405 & 85.3 & 70 & 14.7 & & \\
\hline Donkey or mule & 30 & 73.2 & 11 & 26.8 & $0.47(0.23-0.98)$ & 0.05 \\
\hline \multicolumn{7}{|l|}{ Animals kept in stables } \\
\hline Yes (ref) & 41 & 85.4 & 7 & 14.6 & & \\
\hline No & 394 & 84.2 & 74 & 15.8 & $0.91(0.39-2.10)$ & 0.82 \\
\hline \multicolumn{7}{|l|}{ Contact with cattle } \\
\hline Yes & 369 & 84.4 & 68 & 15.6 & $1.07(0.56-2.04)$ & 0.84 \\
\hline No (Ref) & 66 & 83.5 & 13 & 16.5 & & \\
\hline \multicolumn{7}{|l|}{ Contact with goats } \\
\hline Yes & 53 & 88.3 & 7 & 11.7 & $1.47(0.64-3.35)$ & 0.36 \\
\hline No (Ref) & 382 & 83.8 & 74 & 16.2 & & \\
\hline \multicolumn{7}{|l|}{ Contact with poultry } \\
\hline Yes & 376 & 84.1 & 71 & 15.9 & $0.90(0.44-1.84)$ & 0.77 \\
\hline No (Ref) & 59 & 85.5 & 10 & 14.5 & & \\
\hline \multicolumn{7}{|l|}{ Contact with sheep } \\
\hline Yes & 96 & 90.6 & 10 & 9.4 & $2.01(1,00-4.05)$ & 0.05 \\
\hline No (ref.) & 339 & 82.7 & 71 & 17.3 & & \\
\hline \multicolumn{7}{|l|}{ Rats in the farm } \\
\hline Yes & 347 & 84.4 & 64 & 15.6 & $1.05(0.58-1.88)$ & 0.88 \\
\hline $\mathrm{No}(\mathrm{ref})$ & 88 & 83.8 & 17 & 16.2 & & \\
\hline \multicolumn{7}{|l|}{ Toxic plants in the farm } \\
\hline Yes & 194 & 84.0 & 37 & 16 & $0.96(0.59-1.54)$ & 0.86 \\
\hline No (Ref) & 241 & 84.6 & 44 & 15.4 & & \\
\hline \multicolumn{7}{|l|}{ Age range } \\
\hline Young (Ref) & 80 & 93.0 & 6 & 7.0 & & \\
\hline Adult & 227 & 90.4 & 24 & 9.6 & $0.71(0.28-1.80)$ & 0.47 \\
\hline Senior & 128 & 71.5 & 51 & 28.5 & $0.19(0.08-0.46)$ & $<0.01$ \\
\hline
\end{tabular}

CI: Confidence interval. 
Table 3. Generalized linear model for factors associated with Theileria equi infections in equids from the Ilhéus-Itabuna microregion, State of Bahia, Northeast Brazil. Multivariate analysis, full model.

\begin{tabular}{|c|c|c|c|}
\hline Variable & Category & $\begin{array}{c}\text { Odds ratio } \\
(95 \% \mathrm{CI})\end{array}$ & $P$ \\
\hline \multirow[t]{2}{*}{ Sex } & Female (Ref) & & \\
\hline & Male & $0.94(0.47-1.92)$ & 0.87 \\
\hline \multirow[t]{2}{*}{ Species } & Horses (Ref) & & \\
\hline & Donkey or mule & $0.45(0.19-1.02)$ & $<0.01$ \\
\hline \multirow[t]{2}{*}{ Animals kept in stables } & Yes (Ref) & & \\
\hline & No & $1.94(0.75-4.99)$ & 0.17 \\
\hline \multirow[t]{2}{*}{ Contact with cattle } & No (Ref) & & \\
\hline & Yes & $0.81(0.34-1.92)$ & 0.63 \\
\hline \multirow[t]{2}{*}{ Contact with goats } & No (Ref) & & \\
\hline & Yes & $0.57(0.11-3.01)$ & 0.51 \\
\hline \multirow[t]{2}{*}{ Contact with poultry } & No (Ref) & & \\
\hline & Yes & $0.79(0.31-2.03)$ & 0.63 \\
\hline \multirow[t]{2}{*}{ Contact with sheep } & No (Ref) & & \\
\hline & Yes & $2.96(0.83-10.59)$ & 0.09 \\
\hline \multirow[t]{2}{*}{ Rats in the farm } & No (Ref) & & \\
\hline & Yes & $1.09(0.53-2.24)$ & 0.81 \\
\hline \multirow[t]{2}{*}{ Toxic plants in the farm } & No (Ref) & & \\
\hline & Yes & $0.84(0.43-1.62)$ & 0.60 \\
\hline \multirow[t]{3}{*}{ Age range } & Young (Ref) & & \\
\hline & Adult & $0.66(0.25-1.73)$ & 0.40 \\
\hline & Senior & $0.15(0.06-0.40)$ & $<0.01$ \\
\hline
\end{tabular}

CI: Confidence interval; AIC=428.44.

Table 4. Generalized linear model for factors associated with Theileria equi infections in equids from the Ilhéus-Itabuna microregion, State of Bahia, Northeast Brazil Multivariate analysis, final model.

\begin{tabular}{cccc}
\hline Variable & Category & $\begin{array}{c}\text { Odds ratio } \\
\text { (95\% CI) }\end{array}$ & $\boldsymbol{P}$ \\
\hline Species & Horses (Ref) & & \\
& Donkey or mule & & 0.02 \\
Age range & Young (Ref) & $0.41(0.19-0.89)$ & 0.58 \\
& Adult & $0.77(0.30-1.96)$ & $<0.01$ \\
\hline
\end{tabular}

CI: Confidence interval; AIC= 419.12.

Table 5. Generalized linear mixed models for factors associated with Babesia caballi infections in equids from the Ilhéus-Itabuna microregion, State of Bahia, Northeast Brazil. Bivariate analysis.

\begin{tabular}{|c|c|c|c|c|c|c|}
\hline \multirow{2}{*}{ Variable } & \multicolumn{4}{|c|}{ Equidae } & \multirow{2}{*}{$\begin{array}{l}\text { Odds ratio } \\
(95 \% \mathrm{CI}) \\
\end{array}$} & \multirow{2}{*}{$P$} \\
\hline & \multicolumn{2}{|c|}{ Positive (\%) } & \multicolumn{2}{|c|}{ Negative (\%) } & & \\
\hline \multicolumn{7}{|l|}{ Sex } \\
\hline Male & 43 & 30.3 & 98 & 69.5 & $1.43(0.85-2.40)$ & 0.17 \\
\hline Female (Ref) & 86 & 22.9 & 289 & 71.1 & & \\
\hline \multicolumn{7}{|l|}{ Species } \\
\hline Horses (Ref) & 115 & 24.2 & 360 & 65.8 & & \\
\hline Donkey or mule & 14 & 34.1 & 27 & 61.9 & $2.02(0.90-4.55)$ & 0.09 \\
\hline \multicolumn{7}{|c|}{ Animals kept in stables } \\
\hline Yes (ref) & 22 & 45.8 & 26 & 54.2 & & \\
\hline No & 107 & 22.9 & 361 & 77.1 & $0.33(0.17-0.64)$ & $<0.01$ \\
\hline \multicolumn{7}{|l|}{ Contact with cattle } \\
\hline Yes & 114 & 26.0 & 323 & 73.9 & $1.68(0.69-4.07)$ & 0.25 \\
\hline No (Ref) & 15 & 19.0 & 64 & 81.0 & & \\
\hline
\end{tabular}

CI: Confidence interval. 
Table 5. Continued...

\begin{tabular}{|c|c|c|c|c|c|c|}
\hline \multirow{2}{*}{ Variable } & \multicolumn{4}{|c|}{ Equidae } & \multirow{2}{*}{$\begin{array}{c}\text { Odds ratio } \\
(95 \% \mathrm{CI})\end{array}$} & \multirow{2}{*}{$P$} \\
\hline & \multicolumn{2}{|c|}{ Positive (\%) } & \multicolumn{2}{|c|}{ Negative (\%) } & & \\
\hline \multicolumn{7}{|l|}{ Contact with goats } \\
\hline Yes & 6 & 10.0 & 54 & 90.0 & $0.29(0.11-0.78)$ & 0.01 \\
\hline No (Ref) & 123 & 27.0 & 333 & 73.0 & & \\
\hline \multicolumn{7}{|l|}{ Contact with poultry } \\
\hline Yes & 108 & 24.2 & 339 & 75.8 & $0.67(0.30-1.50)$ & 0.33 \\
\hline No (Ref) & 21 & 30.4 & 48 & 69.6 & & \\
\hline \multicolumn{7}{|l|}{ Contact with sheep } \\
\hline Yes & 17 & 16.0 & 89 & 84.0 & $0.54(0.26-1.10)$ & 0.09 \\
\hline No (ref.) & 112 & 27.3 & 298 & 72.7 & & \\
\hline \multicolumn{7}{|l|}{ Rats in the farm } \\
\hline Yes & 96 & 23.4 & 315 & 76.6 & $0.62(0.32-1.20)$ & 0.16 \\
\hline No(ref) & 33 & 31.4 & 72 & 68.0 & & \\
\hline \multicolumn{7}{|c|}{ Toxic plants in the farm } \\
\hline Yes & 50 & 21.6 & 1.8 & 78.4 & $0.74(0.42-1.33)$ & 0.32 \\
\hline No (Ref) & 79 & 27.7 & 206 & 72.3 & & \\
\hline \multicolumn{7}{|l|}{ Age range } \\
\hline Young (Ref) & 53 & 61.6 & 33 & 38.4 & & \\
\hline Adult & 59 & 23.5 & 192 & 76.5 & $0.19(0.11-0.33)$ & $<0.001$ \\
\hline Senior & 17 & 9.5 & 162 & 90.3 & $0.05(0.03-0.11)$ & $<0.001$ \\
\hline
\end{tabular}

CI: Confidence interval.

Table 6. Generalized linear mixed model for factors associated with Babesia caballi infections in equids from the Ilhéus-Itabuna microregion, State of Bahia, Northeast Brazil. Multivariate analysis, full model.

\begin{tabular}{|c|c|c|c|}
\hline Variable & Category & $\begin{array}{c}\text { Odds ratio } \\
(95 \% \mathrm{CI})\end{array}$ & $P$ \\
\hline \multirow[t]{2}{*}{ Sex } & Female (Ref) & & \\
\hline & Male & $0.81(0.44-1.52)$ & 0.52 \\
\hline \multirow[t]{2}{*}{ Species } & Horses (Ref) & & \\
\hline & Donkey or mule & $2.42(0.95-6.14)$ & 0.06 \\
\hline \multirow[t]{2}{*}{ Animals kept in stables } & Yes (Ref) & & \\
\hline & No & $0.49(0.22-1.09)$ & 0.08 \\
\hline \multirow[t]{2}{*}{ Contact with cattle } & No (Ref) & & \\
\hline & Yes & $1.73(0.66-4.53)$ & 0.27 \\
\hline \multirow[t]{2}{*}{ Contact with goats } & No (Ref) & & \\
\hline & Yes & $0.21(0.04-1.09)$ & 0.06 \\
\hline \multirow[t]{2}{*}{ Contact with poultry } & No (Ref) & & \\
\hline & Yes & $1.23(0.51-2.97)$ & 0.64 \\
\hline \multirow[t]{2}{*}{ Contact with sheep } & No (Ref) & & \\
\hline & Yes & $1.24(0.45-3.43) 0.68$ & 0.68 \\
\hline \multirow[t]{2}{*}{ Rats in the farm } & No (Ref) & & \\
\hline & Yes & $0.72(0.34-1.53)$ & 0.39 \\
\hline \multirow[t]{2}{*}{ Toxic plants in the farm } & No (Ref) & & \\
\hline & Yes & $1.20(0.61-2.36)$ & 0.59 \\
\hline \multirow[t]{3}{*}{ Age range } & Young (Ref) & & \\
\hline & Adult & $0.19(0.11-0.34)$ & $<0.01$ \\
\hline & Senior & $0.06(0.03-0.13)$ & $<0.01$ \\
\hline
\end{tabular}


Table 7. Generalized linear mixed model for factors associated with Babesia caballi infections in equids from the Ilhéus-Itabuna microregion, State of Bahia, Northeast Brazil. Multivariate analysis, final model.

\begin{tabular}{cccc}
\hline Variable & Category & $\begin{array}{c}\text { Odds ratio } \\
\text { (95\% CI) }\end{array}$ & $\boldsymbol{P}$ \\
\hline Species & Horses (Ref) & & 0.02 \\
& Donkey or mule & & \\
Age range & Young (Ref) & $2.94(1.20-7.15)$ & $<0.001$ \\
& Adult & & $<.17(0.10-0.30)$ \\
& Senior & $0.05(0.02-0.10)$ & $<0.001$ \\
\hline
\end{tabular}

CI: Confidence interval; AIC= 499.6.

adult and senior groups indicate that age protects animals from acquiring the disease whereas the other species of equids (donkey + mule) indicate risk of contracting the infection.

Coinfections with hemoparasites were detected in $22.7 \%$ (129/569) of the equidae - 23.6\% (122/516) in animals from rural areas and $13.2 \%(7 / 53)$ in animals from urban areas. Coinfections were detected in equids from all counties and farms studied. Among the equid species tested for hemoparasites in this survey, coinfection was detected in 22\% (116/528) of the horses, in 50\% (4/8) of the mules, and in 27\% (9/33) of the donkeys examined.

At all sampling sites, tick eradication and control measures were adopted in the farms visited. However, ticks were still present in all these farms. Ticks of the following species were identified: Dermacentor nitens, Amblyomma sculptum, and Rhipicephalus microplus.

Trypanosoma evansi DNA was not amplified in any of the blood samples tested. The GAPDH gene was amplified in all samples that were negative for hemoparasites. Hemoparasites were not detected in any of the blood smears examined under the light microscope. There were no significant differences between the results of all the parameters in $\mathrm{CBC}$ and total plasma protein of equids from animals positive for T. equi and B. caballi and animals negative for these hemoparasites. Hematological values remained within the normal reference range.

\section{Discussion}

The present study was conducted in a region where tropical humid climate predominates, which favors the maintenance of the arthropod life cycle throughout the year and perpetuation of hemoprotozoan infections, as cited by Heim et al. (2007). The presence of ticks in all equids sampled confirms this fact, and explains results like: the widespread distribution of equine piroplasmosis and the high prevalence of $T$. equi infection corroborating the results published by Heuchert et al. (1999) and Vieira et al. (2013).

In this study, a higher frequency of $T$. equi infection was observed in comparison with $B$. caballi infection corroborating the findings of previous studies on EP carried out in different regions of the world (BRÜNING, 1996; HEIM et al., 2007; RIBEIRO et al., 2013). Since the ticks Rhipicephalus microplus (BATTSETSEG et al., 2002), Amblyoma cajennense (= A.sculptum) (KERBER et al., 2009; MARTINS et al., 2016), and Dermacentor nitens (HEIM et al., 2007; SANTOS et al., 2009), which are the vectors of both $T$. equi and $B$. caballi, were present in the study area, differences in infection frequency between these two hemoparasitic infections is probably associated with the different forms of transmission and increased pathogenicity of $T$. equi (ALLSOPP et al., 2007), leading to higher and more persistent parasitaemias (DAVITKOV et al., 2016). In addition, the ability of equids to limit B. caballi infection (WEILAND, 1986) and/or the lower prevalence of $B$. caballi in the region (HAWKINS et al., 2015; ODUORI et al., 2015) may also explain the variations between the results of different surveys.

The occurrence of coinfection with T. equi and B. caballi was almost as high as the frequency of $B$. caballi infection. This fact may be the result of the high frequency of T. equi infection (almost $85 \%$ ) since the majority of the animals that tested positive for B. caballi were also positive for T. equi. Coinfections are most likely due to the overlapping distribution of the tick vectors associated with these parasites.

It is important to emphasize that owners and caretakers interviewed did not mention any clinical signs of EP in equids from the farms visited, as described by Baldani et al. (2010) and Guimaráes et al. (2016). This piece of information suggests that most of the hemoprotozoan infections are probably subclinical and asymptomatic as no changes are observed in the $\mathrm{CBC}$ of positive animals, indicating enzootic stability as mentioned by Santos et al. (2011) and Zobba et al. (2008).

The identification of age (adult and senior animals) as a factor that protects animals from acquiring $B$. caballi infection demonstrates that the number of positive animals decreases with advancing (older) age. Since this study was carried out in an area of enzootic stability, the first interaction between the mammalian host and the hemoprotozoan parasite is expected to occur early in life, with a higher prevalence and detection of parasitemia in younger animals (ASGARALI et al., 2007; VIEIRA et al., 2013; WEILAND, 1986). Thus, this finding may be related to the fact that equids are able to limit hemoparasitic infections (WEILAND, 1986), making it difficult for diagnosticians to find the parasite on blood films of older animals. However, this same variation in the number of positive animals depending on the age group has not been observed in previous studies (GRANDI et al., 2011).

Similarly, our results also show that T. equi infection occurs at an earlier age. A number of authors report that, after recovery from acute T. equi infection, animals become healthy, asymptomatic carriers (GUIMARÁES et al., 2016;RÜEGG et al., 2007; VIEIRA et al., 2013; WEILAND, 1986). We expect to find a 
higher prevalence of hemoparasitic infection in older animals since there is a longer time span for the infection to occur as the parasite remains in the bloodstream for prolonged periods of time, possibly throughout the entire lifetime of the animal (RÜEGG et al., 2007; VIEIRA et al., 2013). Baldani et al. (2010) reports that failure to detect T. equi may be due to the reduction of parasitemia of the agent, consequently its DNA, to levels undetectable by molecular biology. In this study, a smaller number of older animals (senior group) were infected with hemoparasites which suggests that the immune system of these equids was able to reduce the parasitemia to undetectable levels by PCR. In addition, since there is no uniformity between studies in terms of categorization by age group, it is possible that differences in this criterion may have influenced results (SANTOS et al., 2011).

In the present study, the lower number of donkeys and mules that tested positive for T. equi in comparison with the number of horses that were positive for this protozoan organism suggests that donkeys and mules are less susceptible to the hemoparasites, or that they could be able to limit such infections. These findings are similar to those published by Hussain et al. (2014). However, García-Bocanegra et al. (2013) and Kouam et al. (2010) suggest that mules are more at risk factor to develop T. equi infections.

However, donkeys and mules were identified as being at increased risk of acquiring $B$. caballi infections. Mules had already been reported by García-Bocanegra et al. (2013), Kouam et al. (2010), and Moretti et al. (2010) as having a higher risk for developing this particular protozoan infection. These researchers attributed the increased risk of this species for being infected with blood parasites to differences that might occur in the management of these animals. These mules are generally used as working animals to carry loads and therefore receive less attention from owners and staff than horses. This hypothesis is also valid for donkeys used for the same purpose in Brazil. Nevertheless, these findings are controversial and not consistent between studies. Piantedosi et al. (2014) noted that horses are potential reservoirs for B. caballi whereas Linhares et al. (1997) and Hussain et al. (2014) did not find any difference in the prevalence of this protozoan infection between each of the three equid species with regard to $B$. caballi infection.

Guidi et al. (2015) compared the prevalence of hemoparasitic infections in several breeds of equids and suggested that variations in the prevalence of these infections is related to the different management practices to which each breed was subjected and not due to genetic susceptibility of each breed to these diseases. This hypothesis would explain the results of several studies, but it does not apply to our study. In our study, the prevalence of each etiological agent of EP in donkeys and mules differed from the prevalence of these pathogens in horses. We assume that in equids genetics plays a role in the occurrence of hemoprotozoan infections and would explain these findings. Alternatively, there may be genetic variability in hemoparasites that are found different geographic regions. This is corroborated by the results of other studies in donkeys only in which $B$. caballi infections was more prevalent than T. equi infections (CHAHAN et al., 2006; GARCÍA-BOCANEGRA et al., 2013; LAUS et al., 2015; MACHADO et al., 2012). The opposite was found in studies involving only horses (RIBEIRO et al., 2013; DE WAAL, 1992).
In the present study, other risk factors which are often reported in the literature such as contact with cattle, grass-fed animals, and the rural environment in comparison to the urban environment (DAVITKOV et al., 2016; GUIDI et al., 2015; HEUCHERT et al., 1999; MORETTI et al., 2010; SHKAP et al., 1998; VIEIRA et al., 2013) were not significantly associated with EP infections in equids. This reinforces the idea that the region studied is an area of enzootic stability with the occurrence of hemoprotozoan infections at an early age and wide distribution of the causal agents of EP in animals and ticks.

It is important to emphasize that in the present survey EP was diagnosed by molecular biology as opposed to the majority of the studies assessing prevalence and risk factors for EP in which serology was the diagnostic tool used. Serological assays yield more positive results for EP than PCR (MORETTI et al., 2010). In light of the above mentioned, it is possible that the prevalence of EP in the studied region is even greater since both diagnostic tests are complementary. The detection of the etiological agents of EP in the blood of the animals tested shows the potential risk of equids in transmitting them to potential vectors and in the maintenance of their life cycles in the area.

In the present survey, the negative results for T. evansi corroborate the lack of reports of clinical cases or outbreaks of trypanosomiasis due to T. evansi in the State of Bahia, Northeast Brazil, where this study was carried out. These findings suggest that probably T. evansi does not occur in the animals from this region of the country. Notwithstanding, as outbreaks of trypanosomiasis due to $T$. evansi (NUNES et al., 2012) have been reported in one area approximately $500 \mathrm{~km}$ from the State of Bahia, strict control over transportation of animals is important as that blood-sucking insect vectors of the disease and reservoirs of the pathogen such as the capybara and the collared peccary are mammals which are widespread in the region.

Based on the results of our study, we conclude that the animals of the area studied are infected early in life with the causal agents of EP, and remain as asymptomatic carriers. Therefore, the movement of young animals from this region could disseminate EP to other areas where the disease do not occur. Adequate measures should be implemented in order to minimize the chances of potential vectors to acquire the pathogen and transmit the disease to susceptible animals. Caution is also required when introducing animals that have not been exposed to the disease into an endemic region. Experimental studies with donkeys and mules should be carried out in order to assess the dynamics of EP in each of these equid species.

\section{Acknowledgements}

This research was funded by Santa Cruz State University (UESC), Ilhéus, Bahia, Brazil. The authors would like to thank owners and staff from the farms included in this study. We also thank Prof. Dr. Rosangela Zacarias Machado, Department of Veterinary Pathology, UNESP, Jaboticabal, São Paulo, Brazil, for providing positive controls for PCR, and Dra. Tatiani Vitor Harvey for the preparation of the images for this publication. 


\section{References}

Allsopp MTEP, Lewis BD, Penzhorn BL. Molecular evidence for transplacental transmission of Theileria equi from carrier mares to their apparently healthy foals. Vet Parasitol 2007; 148(2): 130-136. http:// dx.doi.org/10.1016/j.vetpar.2007.05.017. PMid:17601669.

Aragáo HB, Fonseca F. Notas de Ixodologia. VIII. Lista e chave para os representantes da fauna ixodológica brasileira. Mem Inst Oswaldo Cruz 1961; 59(2): 115-130. http://dx.doi.org/10.1590/S0074-02761961000200001. PMid:13861962.

Asgarali Z, Coombs DK, Mohammed F, Campbell MD, Caesar E. A serological study of Babesia caballi and Theileria equi in Thoroughbreds in Trinidad. Vet Parasitol 2007; 144(1-2): 167-171. http://dx.doi. org/10.1016/j.vetpar.2006.09.015. PMid:17118557.

Ashour AA, Abou El-Naga TR, Barghash SM, Salama MS. Trypanosoma evansi: detection of Trypanosoma evansi DNA in naturally and experimentally infected animals using $\mathrm{TBR}_{1} \& \mathrm{TBR}_{2}$ primers. Exp Parasitol 2013; 134(1): 109-114. http://dx.doi.org/10.1016/j.exppara.2013.02.003. PMid:23454630.

Baldani CD, Nakaghi ACH, Machado RZ. Occurrence of Theileria equi in horses raised in the Jaboticabal microregion, São Paulo State, Brazil. Rev Bras Parasitol Vet 2010; 19(4): 228-232. http://dx.doi.org/10.1590/ S1984-29612010000400007. PMid:21184699.

Barros-Battesti DM, Arzua M, Bechara GH. Carrapatos de importância médico-veterinária da regiāo neotropical: um guia ilustrado para identificação de espécies. São Paulo: Vox/ICTTD-3/Butantan; 2006.

Bates D, Mächler M, Bolker BM, Walker SC. Fitting linear mixedeffects models using lme4. J Stat Softw 2015; 67(1): 1-48. http://dx.doi. org/10.18637/jss.v067.i01.

Battsetseg B, Lucero S, Xuan X, Claveria FG, Inoue N, Alhassan A, et al. Detection of natural infection of Boophilus microplus with Babesia equi and Babesia caballi in Brazilian horses using nested polymerase chain reaction. Vet Parasitol 2002; 107(4): 351-357. http://dx.doi.org/10.1016/ S0304-4017(02)00131-0. PMid:12163246.

Birkenheuer AJ, Levy MG, Breitschwerdt EB. Development and Evaluation of a Seminested PCR for Detection and Differentiation of Babesia gibsoni (Asian Genotype) and B. canis DNA in Canine Blood Samples. J Clin Microbiol 2003; 41(9): 4172-4177. http://dx.doi.org/10.1128/ JCM.41.9.4172-4177.2003. PMid:12958243.

Brüning A. Equine piroplasmosis an update on diagnosis, treatment and prevention. BrVet J 1996; 152(2): 139-151. http://dx.doi.org/10.1016/ S0007-1935(96)80070-4. PMid:8680838.

Butler CM, Nijhof AM, van der Kolk JH, Haseth OB, Taoufik A, Jongejan F, et al. Repeated high dose imidocarb dipropionate treatment did not eliminate Babesia caballi from naturally infected horses as determined by PCR- reverse line blot hybridization. Vet Parasitol 2008; 151(2): 320322. http://dx.doi.org/10.1016/j.vetpar.2007.11.010. PMid:18160222.

Chahan B, Zhang S, Seo JY, Nakamura C, Zhang G, Bannai H, et al. Seroepidemiological evidence for the possible presence of Babesia (Theileria) equi and Babesia caballi infections in donkeys in western Xinjiang, China. J Vet Med Sci 2006; 68(7): 753-755. http://dx.doi.org/10.1292/ jvms.68.753. PMid:16891793.

Davitkov D, Vucicevic M, Stevanovic J, Krstic V, Slijepcevic D, Glavinic U, et al. Molecular detection and prevalence of Theileria equi and Babesia caballi in horses of central Balkan. Acta Parasitol 2016; 61(2): 337-342. http://dx.doi.org/10.1515/ap-2016-0044. PMid:27078657. de Waal DT. Equine piroplasmosis: a review. BrVet J 1992; 148(1): 6-14. http://dx.doi.org/10.1016/0007-1935(92)90061-5. PMid:1551016.

Dohoo IR, Martin S, Stryhn H. Veterinary epidemiologic research. 2nd ed. Charlottrtown: University Prince Edward Island; 2003.

Franke CR, Greiner M, Mehlitz D. Investigations on naturally occurring Trypanosoma evansi infections in horses, cattle, dogs and capybaras (Hydrochaeris hydrochaeris) in Pantanal de Poconé (Mato Grosso, Brazil). Acta Trop 1994; 58(2): 159-169. http://dx.doi.org/10.1016/0001706X(94)90055-8. PMid:7887341.

García-Bocanegra I, Arenas-Montes A, Hernández E, Adaszek Ł, Carbonero A, Almería S, et al. Seroprevalence and risk factors associated with Babesia caballi and Theileria equi infection in equids. Vet J 2013; 195(2): $172-$ 178. http://dx.doi.org/10.1016/j.tvjl.2012.06.012. PMid:22784418.

Grandi G, Molinari G, Tittarelli M, Sassera D, Kramer LH. Prevalence of Theileria equi and Babesia caballi infection in horses from northern Italy. Vector Borne Zoonotic Dis 2011; 11(7): 955-956. http://dx.doi. org/10.1089/vbz.2010.0193. PMid:21254835.

Guidi E, Pradier S, Lebert I, Leblond A. Piroplasmosis in an endemic area: analysis of the risk factors and their implications in the control of Theileriosis and Babesiosis in horses. Parasitol Res 2015; 114(1): 71-83. http://dx.doi.org/10.1007/s00436-014-4161-9. PMid:25280516.

Guimarães AM, Bruhn FRP, Ribeiro MJM, Rosa MHF, Garcia AM, Rocha $\mathrm{CMBM}$, et al. Prevalence and risk factors of Theileria equi infection in horses in Minas Gerais, Brazil. Vet Parasitol: Reg Stud Rep 2016; 3: 18-22. http://dx.doi.org/10.1016/j.vprsr.2016.05.005.

Hawkins E, Kock R, McKeever D, Gakuya F, Musyoki C, Chege SM, et al. Prevalence of Theileria equi and Babesia caballi as well as the identification of associated ticks in sympatric grevy's zebras (Equus grevyi) and donkeys (Equus africanus asinus) in northern Kenya. J Wildl Dis 2015; 51(1): 137-147. http://dx.doi.org/10.7589/2013-11-316. PMid:25380362.

Heim A, Passos LMF, Ribeiro MFB, Costa-Júnior LM, Bastos CV, Cabral DD, et al. Detection and molecular characterization of Babesia caballi and Theileria equi isolates from endemic areas of Brazil. Parasitol Res 2007; 102(1): 63-68. http://dx.doi.org/10.1007/s00436-007-0726-1. PMid:17828553.

Heuchert CMS, De Giulli V Jr, De Athaide DF, Böse R, Friedhoff KT. Seroepidemiologic studies on Babesia equi and Babesia caballi infections in Brazil. Vet Parasitol 1999; 85(1): 1-11. http://dx.doi.org/10.1016/ S0304-4017(99)00108-9. PMid:10447188.

Hoare CA. The trypanosomes of mammals: a zoological monograph. USA: Blackwell Sci. Publ.; 1972.

Hussain MH, Saqib M, Raza F, Muhammad G, Asi MN, Mansoor MK, et al. Seroprevalence of Babesia caballi and Theileria equi in five draught equine populated metropolises of Punjab, Pakistan. Vet Parasitol 2014; 202(3-4): 248-256. http://dx.doi.org/10.1016/j.vetpar.2014.01.026.

Ikadai H, Xuan X, Igarashi I, Tanaka S, Kanemaru T, Nagasawa H, et al. Cloning and expression of a 48-kilodalton Babesia caballi merozoite rhoptry protein and potential use of the recombinant antigen in an enzyme-linked immunosorbent assay. J Clin Microbiol 1999; 37(11): 3475-3480. PMid:10523537.

Instituto Brasileiro de Geografia e Estatística - IBGE. Produção Pecuária Municipal [online]. 2015 [cited 2017 Apr 27]. Available from: https:// ww2.ibge.gov.br/home/estatistica/economia/ppm/2015/

Instituto Nacional de Meteorologia - INMET. Normais Climatológicas (1961-1990) [online]. 2010 [cited 2015 Oct 24]. Available from: http:// www.inmet.gov.br/portal/index.php?r=clima/normaisClimatologicas 
Kerber CE, Labruna MB, Ferreira F, De Waal DT, Knowles DP, Gennari SM. Prevalence of equine Piroplasmosis and its association with tick infestation in the State of São Paulo, Brazil. Rev Bras Parasitol Vet 2009; 18(4): 1-8. http://dx.doi.org/10.4322/rbpv.01804001. PMid:20040201.

Kouam MK, Kantzoura V, Gajadhar AA, Theis JH, Papadopoulos E, Theodoropoulos GG. Seroprevalence of equine piroplasms and hostrelated factors associated with infection in Greece. Vet Parasitol 2010; 169(3-4): 273-278. http://dx.doi.org/10.1016/j.vetpar.2010.01.011.

Lacerda LC, Silva AN, Freitas J, Cruz RDS, Said RA, Munhoz AD. Feline immunodeficiency virus and feline leukemia virus: frequency and associated factors in cats in northeastern Brazil. Genet Mol Res 2017; 16(2): gmr16029633. http://dx.doi.org/10.4238/gmr16029633. PMid:28510253.

Laus F, Spaterna A, Faillace V, Veronesi F, Ravagnan S, Beribé F, et al. Clinical investigation on Theileria equi and Babesia caballi infections in Italian donkeys. BMC Vet Res 2015; 11(1): 100. http://dx.doi.org/10.1186/ s12917-015-0411-z. PMid:25927984.

Linhares GFC, Massard CL, Araújo JLB. Estudo sobre a epizootiologia de Babesia caballi (Nuttall \& Strickland, 1910) na microrregião de Goiânia, Estado de Goiás. Anais Esc Agron Vet 1997; 27(2): 27-33.

Losos GJ. Infectious tropical diseases of domestic animals. New York: Longman Scientific \& Technical; 1986.

Machado RZ, Toledo CZP, Teixeira MCA, André MR, Freschi CR, Sampaio PH. Molecular and serological detection of Theileria equi and Babesia caballi in donkeys (Equus asinus) in Brazil. Vet Parasitol 2012; 186(3-4): 461-465. http://dx.doi.org/10.1016/j.vetpar.2011.11.069. PMid:22186194.

Martins MEP, Brito WMED, Labruna MB, Moraes Filho J, SousaMartins KC, Vieira RP. Inquérito epidemiológico de suposto foco de febre maculosa. Cienc Anim Bras 2016; 17(3): 459-471. http://dx.doi. org/10.1590/1089-6891v17i334947.

Martins TF, Onofrio VC, Barros-Battesti DM, Labruna MB. Nymphs of the genus Amblyomma (Acari: Ixodidae) of Brazil: descriptions, redescriptions, and identification key. Ticks Tick Borne Dis 2010; 1(2): 75-99. http://dx.doi.org/10.1016/j.ttbdis.2010.03.002. PMid:21771514.

Masiga DK, Smyth AJ, Hayes P, Bromidge TJ, Gibson WC. Sensitive detection of trypanosomes in tsetse flies by DNA amplification. Int J Parasitol 1992; 22(7): 909-918. http://dx.doi.org/10.1016/00207519(92)90047-O. PMid:1459784.

Moretti A, Mangili V, Salvatori R, Maresca C, Scoccia E, Torina A, et al. Prevalence and diagnosis of Babesia and Theileria infections in horses in Italy: A preliminary study. Vet J 2010; 184(3): 346-350. http://dx.doi. org/10.1016/j.tvjl.2009.03.021. PMid:19394253.

Muñoz A, Rodríguez RGM, Riber C, Trigo P, Gómez-Díez M, Castejon F. Subclinical Theileria equi infection and rhabdomyolysis in three endurance horses. Pak Vet J 2013; 33(2): 257-258.

Nicolaiewsky TB, Richter MF, Lunge VR, Cunha CW, Delagostin O, Ikuta N, et al. Detection of Babesia equi (Laveran, 1901) by nested polymerase chain reaction. Vet Parasitol 2001; 101(1): 9-21. http://dx.doi. org/10.1016/S0304-4017(01)00471-X. PMid:11587829.

Nunes JTS, Silva AS, Dorneles FSD, Tonin AA, Lazzarotto C, Miletti LC, et al. Occurrence of Trypanosoma evansi in Horses in the State of Minas Gerais, Brazil. J Equine Vet Sci 2012; 32(4): 205-207. http:// dx.doi.org/10.1016/j.jevs.2011.08.023.

Oduori DO, Onyango SC, Kimari JN, MacLeod ET. A field survey for the seroprevalence of Theileria equi and Babesia caballi in donkeys from
Nuu Division, Kenya. Ticks Tick Borne Dis 2015; 6(5): 683-688. http:// dx.doi.org/10.1016/j.ttbdis.2015.05.015. PMid:26072000.

Office International des Epizooties - OIE. Trypanosoma evansi infections (including surra) [online]. 2017 [ 2017 Jun 08]. Available from: http:// www.oie.int/fileadmin/Home/eng/Animal_Health_in_the_World/docs/ pdf/Disease_cards/TRYPANO_EVANSI.pdf

Piantedosi D, D’Alessio N, Di Loria A, Di Prisco F, Mariani U, Neola B, et al. Seroprevalence and risk factors associated with Babesia caballi and Theileria equi infections in donkeys from Southern Italy. Vet J 2014; 202(3): 578-582. http://dx.doi.org/10.1016/j.tvjl.2014.09.025. PMid:25457263.

Qablan MA, Oborník M, Petrželková KJ, Sloboda M, Shudiefat MF, Hořín P, et al. Infections by Babesia caballi and Theileria equi in Jordanian equids: epidemiology and genetic diversity. Parasitology 2013; 140(9): 1096-1103. http://dx.doi.org/10.1017/S0031182013000486. PMid:23673249.

$\mathrm{R}$ Development Core Team. $R$ : a language and environment for statistical computing [online]. Vienna: R Foundation for Statistical Computing; 2016 [cited 2016 June 10]. Available from: http://www.R-project.org

Ribeiro AJ, Cardoso L, Maia JM, Coutinho T, Cotovio M. Prevalence of Theileria equi, Babesia caballi, and Anaplasma phagocytophilum in horses from the north of Portugal. Parasitol Res 2013; 112(7): 2611-2617. http:// dx.doi.org/10.1007/s00436-013-3429-9. PMid:23591484.

Rodrigues A, Fighera RA, Souza TM, Schild AL, Soares MP, Milano J, et al. Surtos de tripanossomíase por Trypanosoma evansi em equinos no Rio Grande do Sul: aspectos epidemiológicos, clínicos, hematológicos e patológicos. Pesq Vet Bras 2005; 25(4): 239-249. http://dx.doi.org/10.1590/ S0100-736X2005000400010.

Rodrigues R, Sanches M, Soares L, Barbosa M, Araújo J, Pessoa G. Análise epidemiológica, clínica e patológica da tripanossomíase "Mal das Cadeiras". Pubvet 2016; 10(2): 118-124. http://dx.doi.org/10.22256/ pubvet.v10n2.118-124.

Rothschild CM. Equine piroplasmosis. J Equine Vet Sci 2013; 33(7): 497-508. http://dx.doi.org/10.1016/j.jevs.2013.03.189.

Rüegg SR, Torgerson P, Deplazes P, Mathis A. Age-dependent dynamics of Theileria equi and Babesia caballi infections in southwest Mongolia based on IFAT and/or PCR prevalence data from domestic horses and ticks. Parasitology 2007; 134(Pt 7): 939-947. http://dx.doi.org/10.1017/ S0031182007002405. PMid:17306055.

Santos TM, Ferraz PN, Almeida FQ, Massard CL, Baldani CD, Botteon PTL, et al. Estudo comparativo de três métodos de diagnóstico para detecção de anticorpos anti-Theileria equi em eqüinos de áreas endêmicas do estado do Rio de. BrazJ Vet Res Anim Sci 2009; 46(6): 484-490. http:// dx.doi.org/10.11606/S1413-95962009000600007.

Santos TM, Roier ECR, Santos HA, Pires MS, Vilela JAR, Moraes LMB, et al. Factors associated to Theileria equi in equids of two microregions from Rio de Janeiro, Brazil. Rev Bras Parasitol Vet 2011; 20(3): 235-241. http:// dx.doi.org/10.1590/S1984-29612011000300011. PMid:21961755.

Sgorbini M, Bonelli F, Nardoni S, Rocchigiani G, Corazza M, Mancianti F. Seroprevalence and Molecular Analysis of Babesia caballi and Theileria equi in Horses From Central Italy During a 10-Year Period. J Equine Vet Sci 2015; 35(10): 865-868. http://dx.doi.org/10.1016/j.jevs.2015.08.011.

Shkap V, Cohen I, Leibovitz B, Savitsky, Pipano E, Avni G, et al. Seroprevalence of Babesia equi among horses in Israel using competitive inhibition ELISA and IFA assays. Vet Parasitol 1998; 76(4): 251-259. http://dx.doi.org/10.1016/S0304-4017(97)00228-8. PMid:9650862. 
Silva RAMS, Herrera HM, Domingos LBS, Ximenes FA, Dávila AMR. Pathogenesis of Trypanosoma evansi infection in dogs and horses: hematological and clinical aspects. Cienc Rural 1995; 25(2): 233-238. http://dx.doi.org/10.1590/S0103-84781995000200010.

Silva RAMS, Sanchez DAMR. Metodologia do teste de imunofluorescência indireta para o diagnóstico da tripanosomose equina. Corumbá: Embrapa Pantanal; 2003. (Circular Técnica; vol. 39).

Starkweather J. Linear mixed effects modelling using $R$ [online]. 2010 [2016 Dec 1]. Available from: http://researchsupport.unt.edu/class/Jon/ Benchmarks/LinearMixedModels_JDS_Dec201

Vieira TSWJ, Vieira RFC, Finger MAP, Nascimento DAG, Sicupira PML, Dutra LH, et al. Seroepidemiological survey of Theileria equi and
Babesia caballi in horses from a rural and from urban areas of Paraná State, southern Brazil. Ticks Tick Borne Dis 2013; 4(6): 537-541. http:// dx.doi.org/10.1016/j.ttbdis.2013.07.005. PMid:24209493.

Weiland G. Species-specific serodiagnosis of equine piroplasma infections by means of complement fixation test (CFT), immunofluorescence (IIF), and enzyme-linked immunosorbent assay (ELISA). Vet Parasitol 1986; 20(1-3): 43-48. http://dx.doi.org/10.1016/0304-4017(86)90091-9. PMid:3518216.

Zobba R, Ardu M, Niccolini S, Chessa B, Manna L, Cocco R, et al. Clinical and laboratory findings in equine piroplasmosis. J Equine Vet Sci 2008; 28(5): 301-308. http://dx.doi.org/10.1016/j.jevs.2008.03.005. 